IMPROVING STUDENTS' LEARNING OUTCOME AND MATHEMATICAL ACTIVITIES THROUGH INQUIRY LEARNING STRATEGY IN CLASS XII IPA-2 SMAN 2 BAGAN SINEMBAH 2014/2015 ACADEMIC YEAR

\author{
PENINGKATAN HASIL BELAJAR DAN AKTIVITAS MATEMATIKA \\ SISWA MELALUI STRATEGI PEMBELAJARAN INKUIRI PADA \\ KELAS XII IPA-2 SMAN 2 BAGAN SINEMBAH TAHUN PELAJARAN \\ 2014/2015
}

\title{
M. Yamin
}

SMAN 2 Sinembang Riau

Email : sayyid.hasid@yahoo.co.id

\begin{abstract}
The purpose of this study is to examine the improvement of students' learning outcome using inquiry learning strategy and to find out the increase of mathematics learning activities using inquiry learning strategy. This study is an action research which was held at SMAN 2 Bagan Sinembah. The subject is students of Class XII IPA-2 in the academic year 2014/2015 which consists of 40 people, 11 male students and 29 female students. This study was conducted in two cycles, each consists of three meetings. A test was conducted at the beginning and at the end of each cycle in order to see students' mathematical communication ability. The results of cycle I showed that students' average score was 72.7 with 25 students complete and 15 students incomplete and the classical completeness was 62.5\%. In the second cycle, the average score was 82.65 with 37 students complete and 3 students incomplete and the classical completeness was 92.5\%. There was an increase of 9.5 points on students' learning outcome and hence it can be concluded that inquiry learning strategy leads students' activities to be in good category.
\end{abstract}

Keywords: learning outcome, students' mathematical activities, inquiry learning strategy

\begin{abstract}
Abstrak, Tujuan dari penelitian ini adalah untuk mengetahui peningkatan hasil belajar dan peningkatan aktivitas proses pembelajaran matematika siswa dengan menggunakan strategi pembelajaran inkuiri. Penelitian ini merupakan Penelitian Tindakan Kelas (PTK) yang dilaksanakan di SMA Negeri 2 Bagan Sinembah Kecamatan Bagan Sinembah. Subjek penelitian adalah siswa kelas XII IPA-2 tahun pelajaran 2014/2015 sebanyak 40 orang yang terdiri dari 11 orang laki-laki dan 29 orang perempuan. Penelitian ini terdiri dari 2 siklus yaitu siklus I terdiri dari 3 pertemuan dan siklus II terdiri dari 3 pertemuan. Tes kemampuan matematika siswa dilakukan di awal dan akhir setiap siklus. Adapun hasil dari penelitian ini dapat dilihat dari: (1) Hasil tes ulangan kemampuan matematika siswa siklus I diketahui nilai rata-rata 72,75, tuntas 25 orang, tidak tuntas 15 orang, ketuntasan klasikal 62,5\%; (2) Hasil tes ulangan kemampuan matematika siswa siklus II diketahui nilai rata-rata 82,65, tuntas 37 orang, tidak tuntas 3 orang, ketuntasan klasikal 92,5\%, dan peningkatan hasil belajar matematika siswa naik 9,5 poin; (3) Pembelajaran dengan menggunakan strategi pembelajaran inkuiri membuat aktivitas siswa berkategori baik dalam pembelajaran.
\end{abstract}

Kata Kunci : Hasil Belajar, Aktivitas Matematika Siswa, Strategi Pembelajaran Inkuiri. 
Edutech, Tahun 15, Vol.15, No.1, Februari 2016

\section{A. PENDAHULUAN}

Pada lampiran Permen 23 tahun 2006 disebutkan bahwa salah satu tujuan dari pembelajaran matematika adalah, memahami konsep matematika, menjelaskan keterkaitan antar konsep dan mengaplikasikan konsep atau algoritma, secara luwes, akurat, efisien, dan tepat, dalam pemecahan masalah. Kenyataan di lapangan terlihat bahwa tujuan dari pembelajaran matematika tersebut belum mampu tercapai secara maksimal di masing-masing satuan pendidikan, tidak terkecuali di kelas XII IPA-2 SMA Negeri 2 Bagan Sinembah. Hal ini dapat dilihat dari hasil ulangan harian yang diperoleh siswa pada pokok bahasan Matrik, Vektor, dan Transformsi geometri hanya mencapai rata-rata 45,83 .

$$
\text { Rendahnya hasil belajar }
$$
matematika siswa di SMA Negeri 2 Bagan Sinembah kelas XII IPA-2 sangat berkaitan erat dengan aktivitas proses pembelajaran yang dilakukan oleh guru selama ini, serta persepsi siswa yang negatif terhadap pembelajaran matematika. Umumnya untuk menghabiskan waktu 2 jam pelajaran seorang guru mengalokasikan waktunya 10 menit untuk mengabsen, 40 menit membahas tugas-tugas yang lalu, 20 menit untuk memberi penjelasan pelajaran yang baru, dan 20 menit memberikan latihan soal. Proses pembelajaran seperti ini jelas akan menempatkan guru sebagai sosok yang memiliki otoritas memaksa. Guru sebagai orang yang paling tahu, paling berkuasa, dan pemberi komando (Moston, 1972:32). Guru menganggap siswa sebagai lembaran putih yang polos yang tidak tahu apa-apa dan siap untuk diisi dengan ilmu.

Padahal dalam belajar matematika agar siswa dapat memahami matematika secara konseptual seharusnya siswa perlu saling berinteraksi dengan teman maupun guru. Menelaah, menghubungkan keterkaitan konsep, membuat dugaan cara penyelesaian dan jawaban atas masalah yang di pelajari, serta mendiskusikan gagasan mereka sendiri. Artinya belajar matematika itu dapat terjadi jika siswa aktif dalam pembelajaran matematika. Hal ini sesuai dengan teori belajar konstruktivisme, bahwa pengetahuan itu akan bermakna manakala pengetahuan itu dicari dan ditemukan sendiri oleh siswa. Oleh sebab itu guru perlu memperhatikan pemilihan strategi pembelajaran yang menyenangkan dan 
Edutech, Tahun 15, Vol.15, No.1, Februari 2016

membuat siswa aktif. Strategi pembelajaran yang dapat diterapkan guru untuk membuat siswa aktif, dan pembelajaran yang menyenangkan adalah dengan menerapkan strategi pembelajaran inkuiri.

Strategi pembelajaran inkuiri merupakan rangkaian kegiatan pembelajaran yang menekankan pada proses berfikir secara kritis dan analitis untuk mencari dan menemukan sendiri jawaban dari suatu masalah yang dipertanyakan. Proses berfikir itu sendiri biasanya dilakukan melalui tanya jawab antara guru dan siswa, serta antara siswa dengan siswa melalui kegiatan diskusi yang mereka lakukan dalam pembelajaran. Intinya strategi pembelajaran inkuiri sangat menekankan pada aktivitas siswa secara maksimal dalam mencari dan menemukan jawaban dari masalah yang di hadapi siswa.

Hasil penelitian Erwin (2011) menunjukkan bahwa pelaksanaan pembelajaran pada siswa kelas IV SD, dapat meningkatkan aktivitas dan hasil belajar matematika siswa. Begitu juga hasil penelitian Agus (2008) terhadap siswa SMAN 14 Medan pada bidang studi Fisika pokok bahasan gerak lurus.
Berangkat dari pemikiran diatas penulis bertekad untuk meningkatkan hasil belajar dan aktivitas siswa pada pembelajaran matematika dengan menerapkan penelitian tindakan kelas. Adapun judul dari penelitian tindakan kelas tersebut adalah "Peningkatan hasil belajar dan aktivitas matematika siswa melalui strategi pembelajaran inkuiri pada kelas XII IPA-2 SMA Negeri 2 Bagan Sinembah tahun pelajaran $2014 / 2015$

Penelitian ini merupakan penelitian tindakan kelas (PTK) yang dilaksanakan di kelas XII IPA-2 SMA Negeri 2 Bagan Sinembah tahun pelajaran 2014/2015. Subjek dalam Penelitian Tindakan Kelas (PTK) ini adalah siswa kelas XII IPA-2 SMA Negeri 2 Bagan Sinembah tahun pelajaran 2014/2015, yang terdiri dari 11 orang laki-laki dan 29 orang perempuan. Pelaku tindakan dalam penelitian ini adalah peneliti yang merupakan guru SMA Negeri 2 Bagan Sinembah dibantu oleh mitra kolaborator (guru matematika SMA Negeri 2 Bagan Sinembah).

1. Pelaksanaan Siklus I

Kegiatan yang dilakukan pada siklus I meliputi perencanaan, pelaksanaan tindakan, observasi dan 
Edutech, Tahun 15, Vol.15, No.1, Februari 2016

evaluasi serta refleksi. Dalam menyampaikan materi pembelajaaran pelaksanaan pembelajaran, peneliti dan satu pertemuan berikutnya untuk menggunakan strategi pembelajaran melakukan tes kemampuan belajar inkuiri.

\section{a. Perencanaan}

matematika setelah mengikuti pembelajaran dengan menggunakan

Pada tahap ini guru mempersiapkan rencana pelaksanaan pembelajaran strategi pembelajaran inkuiri.

Pemberian tindakan pada siklus I (RPP) matematika, membuat lembar difokuskan pada peningkatan hasil kerja siswa (LKS), membuat lembar belajar dan aktivitas belajar matematika observasi guru dan siswa untuk siswa. Pelaksanaan tindakan mengacu mengamati proses pembelajaran dan aktivitas siswa selama penerapan pada rencana yang telah disiapkan berupa pembelajaran dengan tindakan. Menyusun instrument tes menggunakan strategi inkuiri.

matematika untuk mengukur hasil c. Observasi dan Evaluasi belajar matematika siswa, dan Selama kegiatan pelaksanaan siklus penguasaan materi matematika siswa I, semua observer melakukan setelah mengikuti pembelajaran dengan menggunakan strategi pembelajaran inkuiri.

\section{b. Pelaksanaan Tindakan}

Pelaksanaan tindakan pada siklus I pengamatan terhadap aktivitas guru dan siswa dalam pembelajaran, serta melakukan tes kemampuan belajar matematika siswa. Berdasarkan hasil dilakukan sebanyak empat kali disajikan pada tabel dibawah ini. pertemuan. Tiga pertemuan untuk

Tabel. 1.1

Hasil Belajar dan Aktivitas Siswa pada Siklus I

\begin{tabular}{rcc}
\hline No & Aspek & Hasil \\
1 & Aktivitas Siswa & Cukup \\
2 & Hasil Belajar & Cukup \\
3 & Nilai Rata-rata & 72,75 \\
4 & Ketuntasan Klasikal & $62,5 \%$ \\
\hline
\end{tabular}


Dari data diatas terlihat bahwa aktivitas guru dan siswa berkategori cukup. Adapun nilai rata-rata hasil belajar matematika 72,75 dengan ketuntasan klasikal $62,75 \%$. Berdasarkan indikator ketercapaian pada penelitian ini maka perlu diadakan tindakan perbaikan dalam proses pembelajaran pada siklus II.

\section{d. Refleksi}

Berdasarkan hasil refleksi terhadap pelaksanaan siklus I ada beberapa kelemahan yang terjadi ditinjau dari aspek guru, siswa dan hasil tes belajar siswa. Dari aspek guru kelemahan yang terjadi disebabkan oleh kurangnya guru dalam memotivasi siswa, menyiapkan situasi yang mendorong siswa untuk melakukan penemuan, menciptakan suasana belajar aktif, melakukan pengamatan terhadap aktivitas siswa, dan mengaktifkan diskusi kelompok. Sedangkan dari aspek aktivitas siswa dan tes belajar matematika penyebab rendahnya hasil belajar siswa disebabkan oleh: (1) Sulitnya siswa dalam memahami masalah yang diberikan sehingga belum mampu menyelesaikan permasalahan dengan baik, (2) Siswa yang berkemampuan rendah masih lebih banyak diam mendengarkan diskusi sesama teman kelompoknya.

Dari berbagai kelemahan yang terjadi pada siklus I, guru melakukan perbaikan terhadap tindakan pembelajaran agar kelemahankelemahan tersebut tidak terulang pada siklus berikutnya. Perbaikan yang dimaksud berupa: (1) Guru akan melakukan motivasi lebih intensif lagi; (2) Guru lebih intensif dalam melakukan pertanyaan-pertanyaan yang mengarahkan siswa pada alur berfikir yang benar dengan pengumpulan informasi yang dibutuhkan; (3) Guru berkeliling memperhatikan kelompok diskusi dan lebih memfokuskan pada siswa yang memiliki kemampuan rendah pada hasil tes siklus I; (3) Guru akan menyiapkan lembar kerja siswa yang diberikan konsep-konsep dasar yang dibutuhkan dalam menyelesaikan masalah yang tertera pada LKS; (4) Melakukan wawancara kepada siswa yang masih mengalami kesulitan; (5) Mengidentifikasi kesulitan yang dihadapi siswa; (6) Memberikan LKS tambahan terhadap bagian yang belum dikuasai siswa; (7) Memberikan tugas secara individual.

\section{Pelaksanaan siklus II}


Edutech, Tahun 15, Vol.15, No.1, Februari 2016

Berdasarkan hasil refleksi pada pembelajaran dengan menggunakan siklus I maka kegiatan yang dilakukan enam tahap strategi pembelajaran pada siklus II meliputi perencanaan, inkuiri. Enam tahapan tersebut adalah: pelaksanaan, observasi dan evaluasi serta refleksi. Masing-masing kegiatan dapat dijelaskan sebagai berikut.

\section{a. Perencanaan}

Pada tahap ini guru membuat RPP, LKS, lembar observasi aktivitas guru dan siswa untuk mengamati proses pembelajaran dan aktivitas siswa, instrumen tes hasil belajar matematika siswa, serta menetapkan nama-nama anggota kelompok diskusi siswa yang baru.

b. Pelaksanaan Tindakan

Pada pelaksanaan pembelajaran siklus II guru menyampaikan proses

(1) Orientasi, (2) Merumuskan masalah,

(3) Mengajukan hipotesis,

Mengumpulkan data, (5) Menguji hipotesis, dan (6) Merumuskan kesimpulan.

c. Observasi dan Evaluasi

Berdasarkan hasil observasi observer terhadap aktivitas guru dan siswa dalam pembelajaran matematika dengan menggunakan strategi pembelajaran inkuiri, serta hasil tes kemampuan belajar matematika siswa pada siklus II dapat disajikan pada tabel dibawah ini.

Tabel 2.1

Hasil Belajar dan Aktivitas Siswa pada Siklus II

\begin{tabular}{ccc}
\hline No & Aspek & Hasil \\
1 & Aktivitas Siswa & Baik \\
2 & Hasil Belajar & Baik \\
3 & Nilai Rata-rata & 82,25 \\
4 & Ketuntasan Klasikal & $92,50 \%$ \\
\hline
\end{tabular}

Dari data diatas terlihat bahwa rata-rata hasil belajar matematika 82,25 untuk aktivitas guru dan siswa masing- dengan ketuntasan klasikal 92,50\%. masing berkategori baik. Adapun nilai 


\section{d. Refleksi}

Berdasarkan hasil refleksi terhadap aktifitas guru dan siswa diketahui bahwa kelemahan-kelemahan yang dilakukan guru dan siswa saat pembelajaran pada siklus I tidak terulang pada siklus II. Dari hasil tes belajar matematika siswa pada siklus II juga diketahui bahwa nilai rata-rata kelas 82,25 dengan ketuntasan klasikal sebesar $92,50 \%$.

Dari hasil refleksi dan pelaksanaan tindakan pada siklus II dapat disimpulkan bahwa semua yang menjadi indikator pada penelitian ini telah tercapai sehingga tindakan dihentikan.

\section{B. PEMBAHASAN PENELITIAN}

Berdasarkan hasil penelitian yang diperoleh, berikut ini akan di uraikan tentang peningkatan proses pembelajaran, peningkatan aktivitas belajar siswa, dan peningkatan hasil belajar matematika siswa dengan menggunakan strategi pembelajaran inkuiri.

\section{Peningkatan Proses Pembelajaran \\ Berdasarkan lembar observasi guru} diketahui bahwa aktivitas guru pada pembelajaran matematika dengan menggunakan strategi pembelajaran inkuiri pada materi barisan dan deret di kelas XII IPA- 2 SMAN 2 Bagan Sinembah mengalami peningkatan. Pada siklus I pertemuan 1, pertemuan 2, dan pertemuan 3 rata-rata aktivitas guru dalam melakasanakan proses pembelajaran berkategori cukup, cukup, dan baik. Pada siklus II pertemuan 1, pertemuan 2, dan pertemuan 3 rata-rata aktivitas guru dalam melakasanakan proses pembelajaran berkategori baik, baik, dan sangat baik. Peningkatan aktivitas guru dalam mengelola pembelajaran pada siklus I antara pertemuan 1 dan 2 sebesar 1,67\%, pertemuan 2 dan 3 sebesar 5\%, pertemuan 3 dengan pertemuan 1 siklus II mengalami peningkatan sebesar 1,66\%. Pertemuan 1 dan 2 pada siklus II mengalami peningkatan sebesar $0,56 \%$, serta pertemuan 2 dan 3 pada siklus II mengalami peningkatan sebesar $6,11 \%$.

Berdasarkan data di atas dapat juga disimpulkan bahwa guru telah melakukan pembelajaran dengan sebaik-baiknya, serta berupaya agar apa yang telah disampaikan dapat dipahami oleh semua siswa. Selain itu guru juga telah melaksanakan tahapan-tahapan 
Edutech, Tahun 15, Vol.15, No.1, Februari 2016

pembelajaran strategi pembelajaran inkuiri.

\section{Peningkatan Aktivitas Siswa}

Berdasarkan lembar observasi aktivitas siswa diketahui bahwa aktivitas siswa pada pembelajaran matematika dengan menggunakan metode pembelajaran inkuiri pada materi barisan dan deret di kelas XII IPA-2 SMAN 2 Bagan Sinembah mengalami peningkatan.

Pada siklus I pertemuan 1, pertemuan 2, dan pertemuan 3 rata-rata aktivitas siswa dalam proses pembelajaran berkategori kurang, kurang, dan cukup. Pada siklus II pertemuan 1 , pertemuan 2 , dan pertemuan 3 rata-rata aktivitas siswa dalam proses pembelajaran berkategori baik, baik, dan sangat baik. Peningkatan aktivitas siswa dalam prose pembelajaran pada siklus I antara pertemuan 1 dan 2 sebesar 11,89\%, pertemuan 2 dan 3 sebesar 6,11\%, pertemuan 3 dengan pertemuan 1 siklus II mengalami peningkatan sebesar 2,67\%. Pertemuan 1 dan 2 pada siklus II mengalami peningkatan sebesar $4,00 \%$, serta pertemuan 2 dan 3 pada siklus II mengalami peningkatan sebesar $4,67 \%$.
3. Peningkatan Hasil Belajar Matematika Siswa

Berdasarkan hasil tes evaluasi siklus I dan siklus II pada meteri barisan dan deret di kelas XII IPA-2 SMA Negeri 2 Bagan Sinembah terjadi peningkatan hasil belajar matematika siswa dari siklus I ke siklus II.

Pada siklus I siswa yang memperoleh nilai $<80$ sebanyak 15 orang, dan yang memperoleh nilai $\geq 80$ sebanyak 25 orang, artinya pada siklus I ketuntasan klasikal yang tercapai sebesar $62,5 \%$ dengan nilai rata-rata kelas 72,75 . Pada siklus II siswa yang memperoleh nilai $<80$ sebanyak 3 orang, dan yang memperoleh nilai $\geq 80$ sebanyak 37 orang, artinya pada siklus II ketuntasan klasikal yang tercapai sebesar $92,5 \%$ dengan nilai rata-rata kelas 82,25.

Peningkatan hasil belajar matematika siswa antara siklus I dan siklus II, dapat terlihat dari peningkatan persentase ketuntasan klasikal yang mengalami peningkatan sebesar $30 \%$, serta peningkatan nilai rata-rata kelas yang mengalami peningkatan sebesar 9,5 poin. Peningkatan ini terjadi karena siswa telah dapat menyesuaikan diri dengan strategi pembelajaran yang digunakan oleh guru, serta kemampuan 
guru dalam menciptakan pembelajaran yang kondusif sesuai dengan sintak strategi pembelajaran inkuiri.

\section{SIMPULAN}

Berdasarkan hasil penelitian, dapat disimpulkan bahwa penggunaan strategi inkuiri dapat meningkatkan hasil belajar dan aktivitas siswa dalam pembelajaran matematika. Hal ini terlihat dari adanya kenaikan persentasi kenaikan klasikal di siklus I dan siklus II.

Terkait hal tersebut,peneliti mengajukan beberapa saran untuk pembelajaran matematika khususnya pada sekolah menengah atas, yaitu:

1. Kepada guru yang ingin melaksanakan pembelajaran dengan menggunakan strategi pembelajaran inkuiri, agar merancang masalah matematika yang kontekstual terhadap materi pembelajaran yang akan disampaikan.

2. Penggunaan strategi pembelajaran inkuiri sangat baik digunakan apabila orentasi pembelajaran lebih menekankan pada proses pembelajaran.

3. Penggunaan strategi pembelajaran inkuri baik digunakan jika jumlah siswa yang berada dalam kelas tidak terlalu besar.
4. Hasil penelitian ini dapat dijadikan bahan masukan bagi sekolah untuk meningkatkan mutu dan inovasi pembelajaran.

5. Bagi peneliti selanjutnya diharapkan dapat mengadaptasi langkah-langkah yang ada dalam penelitian ini dan memperbaiki kekurangan-kekurangan yang terjadi pada penelitian ini.

\section{DAFTAR PUSTAKA}

Aqib, Z . (2006) . Penelitian Tindakan Kelas Untuk Guru. Bandung: CV Yrama Widya.

Arikunto, S. (2008). Dasar-Dasar Evaluasi Pendidikan Edisi Revisi. Jakarta: Bumi Aksara

Dariyanto. (2010). Belajar Dan Mengajar. Bandung: Yrama Widya

Gulo, A. (2009). Pemahaman Siswa Pada Materi Fungsi Dikelas XI SMA Negeri 1 Kutapanjang Tahun Pelajaran 2008/2009 Kabupaten Gayo Lues.Tesis pada PPS Universitas Megeri Medan, Medan: Tidak diterbitkan.

Hudoyo, H. (1990). Strategi Mengajar Belajar Matematika. Surabaya: Ikip Malang. 
Edutech, Tahun 15, Vol.15, No.1, Februari 2016

Jhonson, Elaine B. (2007). Contextual Teaching \& Learning. Jakarta: MLC

Kunandar. (2008). Langkah Mudah

Penelitian Tindakan Kelas

Sebagai Pengembangan Profesi

Guru. Jakarta: Raja Grafindo

Persada

Kusumah, W. Dwitagama, D. (2009).

Mengenal Penelitian Tindakan

Kelas. Jakarta: Indeks.

Mulyasa. E (2007). Standar Kompetensi

dan Sertifikasi Guru. Bandung :

Remaja Rosda Karya.

Puskur. (2010). Kajian Kebijakan

Kurikulum Mata Pelajaran

Matematika. Tersedia:

www.puskur.net/download/si/sm

a/Matematika.pdf. [19 Pebruari 2010].

Ronis, D. ( 2009 ). Pengajaran Matematika Sesuai Cara Kerja Otak. Jakarta : PT Indeks.

Roza, Y dkk .( 2007). Pendidikan Dan

Pelatihan Profesi Guru Rayon - 5

Fkip Universitas Riau Modul

Penelitian Tindakan Kelas. Pekan

baru: UNRI

Sanjaya, W. (2008). Strategi

Pembelajaran Berorientasi

Proses Pendidikan. Jakarta:

Kencana Prenada Media Group.
Syahputra, ( 2011 ). Peningkatan hasil belajar dan aktivitas belajar siswa Kelas IV SDBudi Mulia Medan dengan menggunakan metode inkuiri. Tesis pada PPS Universitas Negeri Medan, Medan : Tidak diterbitkan

Slameto. (2003). Belajar Dan Faktorfaktor Yang Mempengaruhinya. Jakarta: Rineka Cipta

Sudijono, A. (2001). Pengantar Evaluasi Pendidikan . Jakarta: Raja Grafindo Persada.

Sumiadi. Asra . (2007). Metode Pembelajaran. Bandung: CV Wacana Prima.

TIM MKPBM. (2001). Strategi Pembelajaran Matematika Kontemporer. Bandung: Universitas Pendidikan Indonesia. Trianto. (2009). Mendesain Model Pembelajaran Inovatif Progresif. Jakarta: Kencana Prenada Media Group.

Vande, Walk Jhon A. (2006). Matematika Sekolah Dasar dan Menengah. Jakarta: Erlangga.

69 Peningkatan Hasil Belajar Dan Aktivitas Matematika Siswa Melalui Strategi Pembelajaran Inkuiri Pada Kelas XII IPA-2 SMAN 2 Bagan Sinembah Tahun Pelajaran 2014/2015 